\title{
THE ETA AS OUTCASTES AND SCAPEGOATS AMONG JAPANESE AMERICANS
}

\author{
Rosalie H. Wax \\ University of Kansas
}

\section{Introduction}

For many hundreds of years the lowest position in Japanese social structure has been occupied by the eta, a hereditary outcaste group which performed necessary but despised work.

The presence, in the United States, of a considerable number of persons of eta descent was revealed rather dramatically when the American Government obliged the evacuated Japanese Americans to answer a questionnaire designed to determine whether or not they were loyal to America. When an attempt was made to correlate affirmative or negative answers to the questionnaire with place of residence before evacuation, it was discovered that evacuees coming from certain California communities were almost unanimously loyal to America and obviously had no desire to return or go to Japan. Later the possible reasons for this unanimity were investigated, and it was found that these sections of California had been rather heavily populated by Japanese of eta descent.

The data to be presented were collected under rather peculiar circumstances. ${ }^{1}$ The Japanese Americans had recently been removed to relocation centers, an experience which involved great hardship and discomfort to all of them and great economic loss to most of them. Life within the centers tended to weaken the social and economic distinctions which had existed before the evacuation. All persons, regardless of their status, were obliged to eat in crude, common mess halls, use the public latrines, and conform to a large degree to the rough and ready mores which developed in this extremely crowded and public environment. ${ }^{2}$,

We have here then data on a traditionally mistreated and scorned outcast group, obtained at a time when the majority group was itself suffering from marked discrimination and ill treatment. Following the simple psychological theory that a group which is persecuted by another group too strong to resist will turn its aggression on some convenient and relatively helpless scapegoat, we might expect that ill treatment of the eta would be revived and strengthened in this situation. On the other hand, if we choose to view human beings as predominantly rational, we might hypothesize that because they themselves suffered discrimination, the Japanese Americans would become more kindly' disposed toward the eta.

In point of fact, the latter process did occur to some degree. A much more salient phenomenon, however, was the turning of anger on a relatively new scapegoat group, the informers - those Japanese Americans suspected of reporting proJapanese or anti-administrative activities to the administration. The significance of this development will be treated in some detail in the concluding section of this paper.

\section{Historical Background}

Ninomiya, ${ }^{3}$ in 1933 , gave the eta population of Japan as about 1,300,000. Fully half of these were engaged in agriculture, to which in rural districts they added the occupations of shoemaker and disposer of dead farm stock. In and near cities 
they were chiefly butchers and tanners. Since other Japanese would not engage in meat packing, eta who entered this occupation sometimes became very wealthy.

Ninomiya contends that the eta as a separate status group may be traced back to the preTokugawa period when they functioned as artisan slaves, working as tanners, armor makers, and saddle makers. Old sources indicate that as early as the 9th century certain villages were set apart for persons who performed menial and despised work. The Shinto ideal of cleanliness and the Buddhist repulsion to eating meat and working with the flesh of animals probably contributed to the opprobrium in which the meat eating, leather working eta were held.

However, it was not until the feudal Tokugawa period (1602-1863) with its extremely rigid social structure, that the eta began to suffer extreme discrimination and humiliation. The Tokugawa confined the eta to separate villages, and forbade them to marry out of their status position or to enter the service of even a commoner as servant. The following incident which occurred in 1859 indicates the extent of eta degradation:

In a quarrel between a young eta and several heimin (commoner) youths, the former was beaten to death. Danzaemon (chief of the eta) petitioned the City Magistrate of Edo to apprehend and punish the guilty persons. He was given no answer and again pressed his request. The City Magistrate then handed down the famous decision that the life of an eta was worth only one-seventh of that of an heimin and added that if Danzaemon should still demand that the guilty be put to death he must bring six other eta slain. ${ }^{4}$

As late as 1870 the following list of regulations regarding conduct of eta was issued in the Wakayama feudatory:

1. When meeting people on the street, step off the road.

2. Eta are forbidden to wander around in cities and towns, except from sunrise to sunset.

3. Eta are forbidden to eat and drink in the city. 4. Eta are forbidden to use any headgear except in rainy weather.
5. Eta are forbidden to wear any footwear except zori ( sandals). 5

Following the social upheaval of the Meiji period, the government took formal steps to improve the situation of the eta. In 1871, the Council of State issued the following proclamation:

The titles of Eta and Hinin shall be abolished; and henceforth the people belonging to these classes shall be treated in the same manner both in occupation and social standing as the common people. ${ }^{6}$

But, according to Ninomiya, neither this proclamation nor the activities of liberal members of the upper classes resulted in a significant improvement of the situation of the eta. In the first quarter of the twentieth century, professors, generals, army officers, or conscripts of eta descent were insulted; the names of soldiers of eta descent were not placed on a monument erected to honor soldiers returning from service in Siberia; eta were discriminated against in schools; eta teachers could not find positions; eta often were not allowed to rent houses among other Japanese and were discriminated against in business; tragedy often followed eta intermarriage with persons classed as heimin or "common people."

In 1922 the eta themselves first took up the battle against discrimination. They formed an organization of considerable power, the Suihei Undo (Equality Movement), but their method of dealing with discrimination, which consisted of a "thoroughgoing censure of offenders," brought on a series of conflicts with the police. In 1929 the authorities suspended the convention of the Suihei Undo and, at this point, Ninomiya's narrative ends.

In recent years two factors not mentioned by Ninomiya probably had some effect in mitigating discriminatory treatment of the eta in Japan. The first was national conscription and consciousness on the part of the military authorities that continued prejudice against the eta would injure the solidarity of the Japanese Army; the second was the fact that such discrimination against any oriental group was not compatible with the Japanese Government's policy of "Asia for Asiatics." That the latter factor has had some 
influence is indicated by the statements of Japanese American informants (cases 4,5) who insist that prejudice still exists although the Japanese Government does not approve of it. "Of course, you don't speak of these things because they are now forbidden by the Japanese Government; but the people still remember in their hearts."

\section{The Data}

This study of the eta was not undertaken primarily to add to social scientific knowledge but rather because informants were unwilling to talk about those subjects on which I was supposed to get information. In desperation I invented studies of a social scientific nature, partly in order to become better acquainted with informants and partly to have something to do.

Collecting attitudes on the eta was not, of course, a particularly tactful choice of investigation, since requesting information on sentiments held toward a despised group could easily give offense. Indeed, the Japanese Americans did not like to talk about the eta. Though I interviewed hundreds of informants during two years of field work, the eta were only once referred to without specific inquiry on my part.

In the interests of good form, I began the conversation with a reference to the samurai or shizoku, as the old warrior status group is now called: Only after contemporary attitudes toward individuals of samurai ${ }^{7}$ descent had been obtained and discussed, did I refer to the eta. Often the informant, if questioned about the social structure of feudal Japan, would himself make some reference to the eta and the subject could then be pursued in a natural manner. Isoon discovered that the term shin-heimin was considered more proper than the term eta, although informants often seemed unwilling to use either and preferred to say "one of those." 8

The informants came from widely separated parts of California and were about equally divided between persons with an urban and a small town background. This difference of background does not appear to be related to any significant difference in attitudes. However, the informants, with one exception, were rather well educated, having completed twelve or more school grades either in Japan or in America.

Since the salient differences in attitude appear to be related to the age of the informant and to his future place of residence, Japan or the United States, the data can perhaps be best presented as short case studies, giving the informant's background along with his verbatim statements on the eta. 9

Statements of Issei: first generation Japanese Americans born in Japan

\section{Mr. A.}

Mr. A. was an Issei, about 50 years old. He graduated from the University of California and was respected and influential in pre-evacuation days, having served as an officer of the Japanese Association. At the outbreak of the war he was interned by the Department of Justice, but was later released to join his family in a relocation center. Of the three Issei interviewed, he was the only one who had not made up his mind definitely to stay in the United States.

It will be noted that he regrets his prejudice against the eta but explains that it is not a matter which can be controlled by reason. He states that he would not allow his daughter to marry an eta. Like most informants he contends that community interest in persons of eta descent has declined since the evacuation. $\mathrm{He}$ is aware of but does not necessarily share the common folk belief that eta are afflicted with diseased, red eyes.

"The shin-heimin, that is serious, especially when it gets to Nisei marrying. First they must look up their family history. It (prejudice) is very deep rooted. In my case, I want to be very fair and would like to forget those things, but somehow it's deep rooted from my childhood. I can't mix (with eta) except as a friend. In case of marriage I would not give my daughter to a shin-heimin. It's not because of a particular dislike. It's deep rooted.

"I hear about it (talk of eta) once in a while here but not so much as before evacuation.

"In Japan the shin-heimin really are very unsanitary and maybe because of that condition most of the people of that class have very bad eyes. Their eyes are infected, red, and irritated. Sometimes you 
see in this center a man with irritated eyes who is not well liked. People say he's shin-heimin.

"Before evacuation there were quite a few cases of marriages stopped or separations after marriage if the family found out.",

2. Mrs. B. and her daughter.

Mrs. B. like many Issei women was softspoken and self-effacing. She and her husband had definitely decided to remain in the United States. Her fifteen year old daughter, whom we will call Yuriko, shared the attitudes of most Nisei her age. Yuriko was an only child, and neighbors were generally of the opinion that her parents treated her too indulgently.

The dialogue between mother and daughter, stimulated by questions about the shin-heimin, will be presented in toto. It clearly depicts the differences between the Issei and the adolescent Nisei views. It also provides an interesting illustration of conflict between two personalities, the young and dogmatic idealist and the gently inflexible older woman. Mrs. B. treated her daughter's radical statements with calm tolerance. Nonetheless, I, as listener, had no doubt that Yuriko would not be permitted to keep company with a young man of eta descent.

INTERVIEWER: What do people think about marrying a person of the shin-heimin class?

YURIKO: (with spirit) It wouldn't make enough difference. It's the person themselves that's important. The nisei like the person himself, not his ancestry.

MRS. B.: But people think about it, especially when a daughter or son are going to get married.

YURIKO: That's why I think that if the Nisei get married themselves (without parental interference) they'll find happiness.

MRS. B.: (quietly attempting to change the subject) Some people would prefer their children to marry shizoku (samurai like Mrs. B.'s husband). Not I think everybody. Nowadays the person counts. Feeling is much weaker in this country.

YURIKO: Some of the folks who come from real respectable families--they're stricter.
INTERVIEWER: (re-introducing subject of eta) How do people know when someone belongs to the shin-heimin class?

MRS. B.: Sometimes you could tell. Nobody knows exactly, but everybody doesn't like them. I can't tell the difference in this country, but some people can. One old lady told me that she can tell right away.

The T. family, we were talking about marriage, and the younger son told me he have to find out about a girl first before he goes around with her and before he get in too deep. He might find she was "that class." If so, why he can't marry her. If he likes her, then it's too late. He asked me how he'll find out.

YURIKO: But what if the Nisei's character is real good?

MRS. B.: Well, that's why it's hard to get married in this camp, because they can't find out so much (about ancestry).

YURIKO: I think that thing is silly.

MRS. B.: (calling upon the sanction of American customs, so much admired by her daughter) Even American people are that way, aren't they? $I$ heard if a man is a count and has no money many girls with money like to marry him.

YURIKO: I think investigating (a fiance's) health is good, but not money and things like that...I didn't know about "that class" (eta) until a friend told me about it.

MRS. B.: A lady I know can tell who eta are, but I can't. In Japan they are "low people" (here she made an expressive gesture, lowering her palm parallel to the floor). Sometimes the girls are very pretty.

\section{Mr. C.}

Mr. C. was an Issei, 50 years old, but the most atypical member of that generation encountered during field work. He was an independent liberal of great integrity. He had a B. A. in economics from the University of California, and had worked all his life in occupations far beneath his real ability. This had not embittered or warped him. Indeed, he endured the evacuation with rational equanimity. During crisis situations in the center, he did not hesitate to speak his mind, even though telling people the plain 
truth sometimes put him in grave danger of social ostracism and violence. He himself had no intention of returning to Japan and consistently advised the Nisei that expatriation would be a foolish step. Also, he had no fear of the authorities and once, in open council meeting, bluntly ordered the Project Director to sitdown and listen to him.

The content of the data he gave differs significantly from that of other informants only in that he holds that there are next to no eta in the United States, which of course is not correct. The manner of his presentation, however, was very different from that of other Issei. In the first place, he took pains to make sure that I understood that he himself had no prejudice. Secondly, in contrast to all other informants, he did not hesitate to tell me that in his opinion my attempt to study the extent of survival of the old class stratification was, for all practical purposes, a waste of time. Such remnants as remained were not socially significant. By and large, of course, he was right. But being courteous and agreeable, he gave me what information he could.

"I have no class distinction on my part. I don't have no fear of a title holder. I feel no personal pride over any very plain guy in the hill-billy country. To me, everybody's human and the same.

"But what I fear socially in American customs is marriage (neglect to investigate the health of a proposed spouse's family). It is necessary to consider the taint of infectious diseases such as epilepsyhand T.B. (tuberculosis) lineage. That is a point in which I say the American custom is unhealthy. It's a good thing to know what family your husband is.

"Princes or etas in the United States are so negligible there is no use to study them. There may be some who look into what degree of warrior descent they have and have pride in their hearts.

"There are very few eta; their number is so small that it's no account at all. In pre-war time, in Los Angeles or San Francisco colonies, there were some persons who were looked down on as eta. I haven'theard about any in this camp.

"Personal ability is more respected than lineage among Nisei. I don't see much class distinction in the younger generation at all. It is almost nil as far as I see.

"But the eta feeling is still found among the Nisei, though vaguely, because they heard it from their parents. But especially among the Issei, regardless of broad-mindedness, they still have a dislike for the eta.

"Even in my childhood days (in Japan) the eta were allowed to attend public school, even among the grammar school children. But they were still looked down on. Eta children used to have a hard time. They knew what they were and they didn't even try to mix among the average children, except in the functions of school activities.

"In this country (U.S.) a butcher can be a big potato. But in Japan even though they have great wealth, they are nothing. ${ }^{10}$ In my childhood in Nagasaki there was a big meat packer who had a lot of money. But he had only daughters. Naturally, he wanted to have an adopted son. ${ }^{11}$ They were an exceptionally wealthy family and had two beautiful daughters. Because of his wealth and the beauty of his daughters, the father didn't want to get a mukoyoshi from the eta group, but from the non-eta group. But on one wanted to go and be a mukoyoshi, regardless of the wealth and the beauty of the women.

"It is said that in Japan there were originally no eta. Originally they are said to be Koreans brought in by Hideyoshi's generals whom he sent on an expedition to Korea. While these Koreans have been treated pretty well by the shogunate government, after all, they were foreigners and in feudal times a foreigner was a stranger and non-social among the aborigenes. Gradually they separated from the rest of the group and took up repulsive occupations.

"The eta group have physically different features from the Japanese. They are much better looking. They are taller. Their main facial feature is lack of sternness. They have much more gentle faces. That's general talk. Of course, I know from anthropology that such things are really hard to distinguish.

"Occasionally there are tragedies in Japan like a young man and woman might get married and in the course of time somebody might look up their ancestry. Things like that don't happen in a town or village at all, only in a big town or city where strange people gather." 
Attitudes of Nisei, planning to return to Japan or undecided on this matter

4. Mr. D.

Mr. D. was of samurai descent. Although born in the United States, he received most of his primary and secondary education in Japan. ${ }^{12} \mathrm{He}$ was about 28 years old, an able draftsman, and had obtained an excellent position just before the evacuation. He resented the evacuation bitterly and determined to return to Japan.

It will be noted that in contrast to Nisei who intended to remain in the United States (cases 8-11) he accepted the treatment of eta as a sociological fact to which one must accommodate. While he does not defend discrimination and even states that the Japanese government disapproves of it, he feels nothing can be done in the face of popular attitudes.

While neither he nor Mrs. F. (case 6) appear to be ashamed or embarrassed by discrimination against the eta, they both attempt to correlate it with sociological phenomena met with in the United States, Mr. D. with the treatment of Negroes, and Mrs. F. with her notion that Americans are reluctant to marry into the families of cattle-raisers or undertakers. These remarks may have been an attempt to justify their prejudices by "sharing the guilt" with Americans. On the other hand, these informants may merely have been attempting to give me an example of parallel sociological phenomena.

"The feeling that eta are low is still going on even in America. They are lowest class in Japan, almost as low as a slave. I heard they were captured in war, Koreans, Chinese, Mongols, or South Sea Chinese. Just like the Negro in time of the Civil War used to be a slave.

"Eta marries eta; heimin (common people) marries heimin. If a heimin marries an eta, everything is washed out. They have no class. They take the most disgrace.

"If you have a girl eta, it means she never gets married, even if she's pretty or the family's got money.

"Nowadays, the Japanese Government says we don't have any classes. But even if the government say such a thing, people still use the old system. When you want to get married, they look up all the history of the family. If they find anybody eta in that family, automatically, they're out."

5. Mr. E.

Mr。E. was a Nisei in his middle twenties. He received all of his education in the United States and graduated from high school at the head of his class. He did, however, decide to expatriate to Japan. He denied that this decision sprang from bitterness toward America and gave as his reason the fact that he had made a mukoyoshi marriage ${ }^{13}$ and thereby assumed economic responsibility for his wife's family, which included her parents and several unmarried sisters. Whereas Mr。 D. delivered his remarks on the eta.as if he were reciting the ten commandments, Mr. E., while stating that he himself would not marry an eta, implied that he thought the prejudice old fashioned and wrong, but too powerful to ignore.

"Things like that are vanishing gradually (in America). It's very seldom you hear of an eta. But some of the Issei still talk about it. Yotsu they call them.

"All the Issei strongly disapprove of marrying eta. As far as talking is concerned, things like that are not mentioned because the Japanese Government doesn't recognize them. But it stays in the hearts of the people.

"I wouldn't marry an eta. The Japanese think if you marry an eta, it's sort of disgraceful to your family or your name. They've been doing dirty work. They make shoes.

"At present the Emperor gave the order that eta are to be classified as heimin (common people). But in Japan, that (discrimination) is still being practiced. When they have a party or festival in Japan, the samurai sit at the top near the priest and the others down the line. The eta are lowest."

6. Mrs, F.

Mrs. F. was a Nisei in her early thirties. She had lived in the United States all of her life, except for a visit of one month to Japan. She was married to an Issei and had five children.

Her husband had been arrested and interned because of alleged pro-Japanese activities. According to rumor he had dressed in a kimono 
and rendered the Japanese national anthem in the mess hall. Concerning these activities, Mrs. F. remarked to me:

"I told him he wouldn't get any place acting like a darned fool. What did he get for all his talk? Stuck in Santa Fe (the internment center). Humpf!"’

At the time this interview was held, Mr. F. was under great strain. Her husband, with whom she had never been particularly happy, hadbeen interned for many months. She had begun a relationship with a Nisei, who wished her to leave her husband and marry him. She was by no means sure that she wished to follow her husband to Japan and, in private conversation, would swing from aggressive pro-Japanese statements to denunciations of the hardships inflicted on women in Japan. She expressed hostility against any convenient target: she irritated the social welfare workers by incessant complaints; she denounced her neighbors either as spineless slaves of the War Relocation Authorities administration or as foolish pro-Japanese troublemakers.

Mrs. F. was the only informant who evidenced an obviously hostile and authoritarian attitude toward the eta. Interestingly, she was also the only informant who immediately told me that she herself was of shizoku descent.

Her mental confusion, apparent to any competent observer, was also revealed in selfcontradiction. She stated that one could not tell an eta by appearance and immediately thereafter insisted that one could.

"Like myself, I'm shizoku. When I went to Japan it said on my passport, my name and right next to it, shizoku.

"Even though we associate with each other, we still think shin-heimin is shin-heimin. If they get too classy we say, "What are you talking about, you shin-heimin!' We keep them up!

"I tell them, 'If you were in Japan, you couldn't even talk to us.' In this country we eat and drink together, but not in Japan.

"Especially in marriage. We never agree (to it).

"By looking at them you can't naturally tell. Sometimes you can tell by talking about the old country in Japan. Sometimes, they say, you can tell by their face or their build. (with emphasis) YOU CAN TELL! We hear and see it with our own eyes. They are different too, in the long run.

"The shin-heimin has more good looking girls and men than the heimin. Their skin is different too. It's just like the difference between a normal person and a T.B. It's sort of transparent.

"It (the difference between eta and others) is something that really doesn't come to your mind. It's something a little different, that's hard to explain.

"That's how we see through them. When they get old they're more dirty and haggy. Before (in Japan), they used to eat too much meat, too much food; that is not proper. Their eyes get mechacha, gummy, not clean. Even among the young people they have gummy eyes. They get cut socially if they marry heimin or since they couldn't get along with the heimin, the heimin husband or wife has to live with the shin-heimin.

"Nowadays in Japan they have just as much privilege as the heimin but still nobody works among them.

"It's the same thing in this country. Like cattle-raisers or undertakers, many people wouldn't give their daughters to them in marriage.

"Some of them (eta), it's like their conscience is hurting them. They feel that they are one (an eta). Some don't even look human, more like a monkey or a gorilla."

\section{Mr. G., Mrs. F.'s brother.}

Mr. G. was several years younger than his sister and like her had spent almost all of his life in America. He was married, had one child, and stigmatized himself as disloyal to America largely because he did not wish to be urafted. Though inclined to be overly cynical, he was a young man of extraordinary common sense, an excellent worker, and one of my more reliable informants.

His comments on the eta provide a marked contrast to those of his sister. Unlike her, he shows no antipathy, and, in general, exhibits attitudes resembling those of Nisei who intend to remain in the United States.

About six months after this interview, he informed the administration that he was nolonger disloyal. Eventually he was allowed to resettle in the United States.

Unlike his sister, he never told me that he was of shizoku descent. 
Mr. Go's wife, who interrupted the conversation at one point, was the only informant who offered a personal experience of the prohibition against marrying eta, her family having forbidden her to keep company with a young man suspected of belonging to that group.

"You'll probably find among the Nisei they still draw a line between the shin-heimin and the others. 'There is just that difference between what you might call blue bloods and the working class.

"It's not just a matter of empty pride, for, when you stop to consider that if, for instance, you were to repatriate and go back to Japan, the differentiation between the two classes, the shinheimin and the others, would be so apparent that you couldn't disregard it back there.

"Whereas here in this country people don't pay so much attention except in case where a young couple want to get married. Then they go into the family background and if one of the young people is found to be eta, you'll find that in 99 cases out of a hundred the combination is broken up, regardless of the feeling of those concerned. Naturally, the couples concerned wouldn't want to break up, but the parents insist because they consider what would happen if they went back to Japan.

"Except for the difference in color it's pretty much like the difference between a Caucasian and a Negro. To look at them you sometimes can't tell the difference between a Caucasian and a high yellow. But the background is different. In the old country the shin-heimin thus far have never been allowed to mingle with the people in social life and business enterprise. They almost always have to live in a separate little town on the outskirts of the main town. The so-called heimin probably wouldn't let them come inside the house.

"I have heard of cases in this country where a young couple got married, For some reason or other no formal investigation of the families was made. Then they went back to the old country to live. The girl was shizoku and didn't know the man was eta. Naturally, that's the first thing they ask. They got to talking about where the girl's husband came from and all the dirt came out. They ordered the poor girl out of the house. 'Never darken my doorstep again' stuff.

"In this country you don't find it so much. I or my friends might know the fellow is of that descent but we wouldn't cut him dead. But I wouldn't let a daughter of mine marry one.

"I think it's just something that's in the mind. If a fellow of that extraction is a decent sort, he should be able to rise above it.

"I think it's been pounded in for generations and generations. But it will die down here (in U.S.).

"There is a case I know of even here in camp where some parents expressly forbade a girl to go out with a boy who they suspected of being eta."

Here Mrs. G。 interrupted:

"That happened to me. I was going out with a fellow and I was bawled out from every direction, my grandfather, my grandmother, my mother and father, my employer, and even him (her future husband)."

Mr. G。 continued:

"In one case a girl married the guy regardless of what her folks and everybody else said. As a result her older brother cut her dead. He himself, when he was younger, married an eta and as a result there actually wasn't any discrimination against him or his wife, but just knowing he was married to an eta affected him. If he thought he had received any small slight it seemed to make him think that it was because he was married to this girl. They really lived a miserable life. She's dead now. After she died his younger sister met this shin-heimin man and she wanted to marry him. He tried to stop her. But the girl was young and very much in love. She just told him off. He didn't want her to suffer as he had.

"There's another fellow in this camp. I've known him all my life. He's twenty-seven years old and still unmarried. Enough said. I doubt if he's ever gone out with a girl steady. But he doesn't want to marry an eta girl. It's family pride with him. He wouldn't want to call it to the attention of other people.

"There's supposed to be a difference in the facial features. In the pronounced eta the skin in that area covering the bridge of the nose, from the corner of one eye to the corner of the other is drawn tightly over a pronouncedly low bridge.

"When the girls are good looking they are unusually good looking. But when they're bad looking there's no getting around it. 
"Red eyes as far as I understand are also one of the pronounced characteristics. Another is, in a large majority of cases, the eyes of young kids four to five years old have inflamed lids with an accumulation around them that gives them a scabby appearance.... But in this country they keep their house as clean as the Japanese."

\section{Statements of Nisei planning to remain in the United States}

8. Mr. H., his wife and friends.

Mr. H. was a Kibei, that is, a Nisei who had received much of his education in Japan. He was in his early thirties. His wife, however, had lived all of her life in the United States. There follows an account of a conversation between this couple and two male Nisei friends on the subject of the eta.

Mr. H. did not approve of discrimination against the eta. Yet, he remarked with a grimace of disgust, "They're just kind of dirty." He said that in Japan he spoke to them but never made friends with them. "You just couldn't think of going to their houses."

In his community the eta lived in a separate smaller village across the river. The boys were accustomed to bring to school small quantities of tea, which were pooled in a common pot. When an eta boy brought some tea, some of the boys did not wish to drink it. This boy, according to Mr. H. was extremely dirty. His clothes were filthy and his sleeves were all shiny where he had wiped his nose on them. But the objections of the boys were over-ruled by the more liberal members of the class.

The eta boys were not invited to the end of the term party. Mr. H. explaining that "I was always sort of soft-hearted." I happened to pass one of them on the street. "Are you coming to the party?" he asked. "No," said the eta. "Come on over," said Mr. H. "He was so glad it made me feel bad; it sort of choked me and made tears come to my eyes."

Mrs. H. thereupon denounced discrimination against the eta. She and the friends present related several incidents of marriages which were stopped or broken up because one partner was of eta descent. One of the friends stated that he knew some eta well. "If you go into their kitchens you can't tell the difference from other people."

Mrs. H. related that when her brother married, his family wished to have the girl's family investigated. Her brother refused to allow the investigation to take place, saying "I'm not marrying her whole family background or her family tree." Mrs. H. added, however, that if their father had been alive, he might not have allowed the marriage to take place.

A friend present remarked, "Even if I do find out that a person is eta, it makes no difference to me. But with a lot of Issei it makes a lot of difference."

\section{Miss I.}

Miss I. was a Nisei in her middle thirties. Of shizoku descent, she had graduated from the University of California and was employed as a social service worker in the center. She did not reveal her own attitudes particularly well, except to indicate that she would hesitate to marry an eta. Nonetheless, the cases she refers to are probably somewhat more reliable than those offered by some of the other informants.

"In my first year at Cal. (U.C.) a Japanese girl took me aside and said, 'Don't be too friendly with so-and-so because she is eta class.' Imight have worried if it had been a boy--but I didn't have to snub her or anything.

"I know that they refer to some people here in camp as being 'that'--'So what can you expect,' they say.

"I knew one girl here. I was just amazed that she came from that class. She was an outstanding person. But she and her husband never began to call on people. The people she lived near said, 'She is peculiar. She has odd ways.' Even here in camp people who know themselves to be eta keep away from the others.

"When marriage is involved the parents will put their foot down. I know of one case where an eta man married and found it out later. He was threatening to kill himself and shoot his son. His wife was a strong Christian. She begged him not to and averted tragedy.

"Another couple were just about to get married. Then the parents found out. He coolly told her he had obligations to his parents and didn't marry her.

"Another case was of a girl who killed her- 
self and committed suicide because she didn't know she was of the eta class. It seems she found out and that made life unbearable."

\section{Mrs. J.}

Mrs. J. was a Nisei in her early twenties, trained in secretarial work. Her husband was a dentist. With the exception of Yuriko B. (case 2) she was the youngest person interviewed about the eta. A bright, witty, and capable young woman, very American in behavior, her relative lack of prejudice against the eta is probably typical of the age group to which she belonged.

"There were a great many (eta) in our town (in California). But I couldn't tell the difference. The only way I know who they are was by the Issei. They said, 'They're one of those.' They looked just the same to me.

"In school I didn't have any very close friends. But (eta or not) we were all friends. There was no discrimination in parties among us younger people.

"But it seems the older people, the Issei eta, stuck together. They would talk to other Issei, but they barely ever associate. If they do, a noneta will go down a rank. I haven't heard of any cases of intermarriage.

"My mother told me there are quite a few eta in this country because in Japan they're not accepted. So to get away from it they come here. But still, I don't know how or who finds out, but they find out and go like this. (Here Mrs. J. raised four fingers, which signifies shihon, animal-like).

"They say if you should marry one you could never go back to Japan. Discrimination is pretty bad in Japan. Here they can go anywhere they please. But in Japan people won't let them in certain places.

"My husband came in the other day and said, 'I heard of a fellow we know who is one of those.' We don't feel that way toward them atall, but he just said that. My husband said (of this man), 'He married with a person who is one of those, so he must be one, too.'

"I sometimes wonder if they don't make a mistake about them. If somebody told me I was one of 'those,' I couldn't prove it.

"My very good girl friend likes a fellow called T. They wanted to marry. Her folks found out he was one of 'those.' They told her they would disown her if she married him. On the other side, his family objected to his marrying an outsider. It was funny. Both sides had objections. All the etas got together and said, 'We don't want you. You mustn't marry her.' She was quite broken hearted about it.

"I know a man back in California who made it practically his business to go around finding out who was an eta and who wasn't. Every time he came around, he said, 'I found out some more. You know who?' That's how I found out there were so many of them. I didn't know before.

"They say so many of the eta's daughters are very beautiful. I didn't notice it. Some I saw were certainly below average in looks.

"Some Issei are so proud of "being eta that they come out and tell you that they are eta. I don't know whether they really are proud or if they think, 'If you want to know, I'll tell you.'

"If I had wanted to marry an eta I know my mother would object. But my brother wouldn't. $\mathrm{He}$ is against all such things (discrimination)."

\section{Mr. K.}

Mr. K. was a Nisei in his middle-twenties, capable, ambitious, and very American in his behavior. He was the only one of the informants who showed a pronounced emotional reaction to the very idea of social discrimination. He became excited and angry and burst out with:

"I don't believe in that! They're notmarrying their ancestors!"

$\mathrm{Mr}$. K. then denied knowing anything about the eta. Only after about a half hour of conciliating conversation could he be induced to return to the subject.

"I used to hear abouteta on the outside (before evacuation) but that (the interviewer's remark) is the first time I've heard about it in here. On the outside you used to run into it once in a while. At first I didn't know what it was.

"You know how I came across what the word eta means? Once I was talking to an old man, an Issei. He says that the Japanese in America meet with considerable discrimination. But, he said, we meet with the same thing in Japan.

"I didn't know what he meant. Later on, I asked somebody about it. He said, 'Don't you 
know? He's an eta.' 'What do you mean?' I said. He told me that eta is a class of people in Japan very despised and looked down on. 'He's one, so he's explaining it to you. He's looked down on by Americans and also by the heimin group in America.' That was the first time I heard about it."

\section{Conclusions}

These data offer evidence of a noteworthy number of changes in sentiment regarding the eta.

Derogatory sentiments toward the traditional outcast group have progressively weakened among the descendants of Japanese immigrants to America; while older immigrants retain some of the status feeling of their youth, mature individuals of the second generation retain less, and adolescent individuals of the second generation retain still less.

The evacuation appears to have increased this tendency toward mitigation of prejudice. A number of informants stated positively that the relatively moderate pre-evacuation discrimination against the eta was decreased even more by the evacuation and life within the relocation centers. These assertions are corroborated indirectly by the fact that during the two years in which I studied the centers I came across no evidence of anti-eta feeling whatever. Had I not undertaken this study, I, like some of the Nisei, would have known only vaguely that a group of people, called eta, were considered outcasts in Japan.

Whether or not there exist some remnants of discrimination on the level of general social intercourse is difficult to say. That a much mitigated discrimination in marriage is retained among the Nisei is obvious, butmost Nisei insist that other forms of discrimination have entirely disappeared. Nevertheless, refraining from snubbing eta at. school and participating with them in school parties does not constitute complete absence of status differentiation. It is not at all unlikely that some Nisei, especially if subjected to community pressure, would hesitate to develop intimate friendships with persons known to be of eta descent. On the other hand, since such descent is easy to conceal, and, if we accept current tales, is often unknown to the eta himself, discrimination on the level of social intercourse can not be very prevalent or very efficient.

When, however, Japanese Americans began to think seriously of leaving America and taking up residence in Japan their attitudes toward discrimination undergo an additional subtle change. Their statements show that they are much more aware of restrictions on association with, eta and indicate that they personally intend to comply with these customs even though they may disapprove of them.

Aside from these phenomena of change, some interesting folk beliefs are voiced. Like many groups with whom sexual or social intercourse is barred, the eta are conceived of as both unusually repulsive and unusually attractive. They are dirty, and have sore, scabby eyes; on the other hand they are handsomer and softer featured than the other Japanese and the women are unusually beautiful. Amusingly, the only dissenter from the folk attitude of eta female beauty was a young and attractive woman (case 10).

In addition to these changes in sentiment toward what might be called the traditional scapegoat of Japan, sociological developments within the centers resulted in an entirely different but extremely interesting change, that is, a shift from the old scapegoat, the eta, to a new one, the informer.14 Apparently, the selection of a scapegoat group is not always determined by cultural tradition or custom but may be significantly influenced by the specific nature of a new sociological situation. 15 In all of the centers, the chief targets of popular ire were unfortunate individuals called inu (literally dog, but in this connotation: stool pigeon). These inu, it was widely and often incorrectly believed, betrayed their own people, either for money or out of malice, by reporting anti-administrative or pro-Japanese statements and activities to the authorities.

Community punishment of suspected inu ranged from very painful social ostracism to violent physical assault. The extent to which hostility toward inu was supported by public opinion is shown by the fact that two of the major center uprisings against the War Relocation Authority immediately followed the arrest of persons suspected of having taken part in inu beatings.

An attempt to explain why this particular change in scapegoats was made in this specific 
situation is not within the scope of this paper, Nevertheless, two tentative hypotheses will be suggested in the hope that they may be of use to anyone undertaking a broader investigation of such a change.

First, it will be noted that while the phenomenon of hostility toward the inu contained many irrational elements, it was more rational in this specific social situation than hostility toward eta. Individuals who betrayed their fellow Japanese to the authorities did exist and provided a very real threat. Anyone who expressed proJapanese sentiments knew that these might be reported. Even when an individual felt relatively secure, the presence of inu provided an annoyance. For example, a notoriously pro-American individual, justly angry over some administrative action, might feel like relieving his emotions by a hot-headed criticism of the American government or the administration. He was, however, obliged to make such a statement only in the presence of trusted friends, lest it be reported and misconstrued. The eta, on the other hand, provided no such threat.

Moreover, hostility toward the inu functioned not only to strengthen group solidarity against the administration, which hostility toward the outgroup eta would also have done, but it provided a powerful negative sanction against the

${ }^{1}$ The study was begun in late 1943 and continued irregularly until early in 1945, while I was engaged in research on the social processes occurring within the relocation and segregation centers where the Japanese Americans were confined during World War II. The read. er curious as to these processes is referred to my article, "The Destruction of a Democratic Impulse," Human Organization, XII, 1 (Spring, 1953), 11-21 and my "The Development of Authoritarianism," unpublished Ph.D. dissertation (Dept. of Anthropology, University of Chicago, 1951). A more general description of the evacuation process and the centers, which is based extensively on my field work, will be found in the volume, published under the names of Dorothy Swaine Thomas and Richard S. Nishimoto, The Spoilage (Berkeley: University of California Press, 1946).

${ }^{2}$ Even educational or professional accomplishments yielded little status, since Japanese American doctors, lawyers, or social workers received wages of nineteen dollars a month, which was but four dollars more than the wages of unskilled laborers.

${ }^{3}$ The brief historical sketch I here offer is based on the comprehensive account of Shigeaki Ninomiya, "An Inquiry Concerning the Origin, Development, and Present Situation of the Eta in Relation to the History of Social Classes in Japan," The Transactions of The Asiatic most heinous crime of the centers-informing. Though it was in part pathological it was also in part useful. To persecute dirty, scabby eyed, or effeminate individuals would not have been equally useful.

Secondly, persecution of inu rather than eta is compatible with the psychological hypothesis that a scapegoat is selected primarily because he can be made to bear the sins of the persecutor. In other words, an individual suffering from shame or guilt escapes punishment by denying his own guilt and attributing it to someone else. The Japanese Americans had been accused of gross disloyalty to the United States. Their very incarceration in centers could be interpreted as punishment. Their harsh experiences aroused natural resentments against the government which, when viewed by a strict conscience, amounted to disloyalty. In this subtle sense the Japanese Americans were guilty of the charges made by that great figure of authority - the United States government. Thereupon they eased their guilt by punishing those persons who committed a similar crime, that is, were disloyal to the Japanese group and who, by their very attachment to the United States government, served as an uncomfortable reminder of the obligations which the angry and disgruntled Japanese Americans were unable to fulfill.

Society of Japan, Second Series, Volume X (1933), pp. 47-154.

${ }^{4}$ Ibid., p. 98.

5 Ibid., p. 109.

6 Ibid.

7 Informants' statements on the samurai or shizoku indicated that the descendants of this group possess relatively little prestige. Persons of shizoku descent were proud of their lineage but considered it poor taste to emphasize it. Informants agreed that the only area in which such descent influenced behavior was in the arrangement of marriages, where socially ambitious parents might prefer a shizoku suitor over a commoner.

${ }^{8}$ Other and more insulting terms than shin-heimin are shihon (four-legged, i.e. animal-like); Yotsu (four, less than five, i.e. imperfect and animal-like); umanokawakagi (horse-skinner); umanohone (horse's bone).

${ }^{9}$ Unfortunately, this study of the eta was only just begun when it had to be abandoned because of the more pressing interests (reported in the works cited in reference note one above). Readers curious as to the problems of field work under these trying conditions may be interested in my "Reciprocity as a Field Technique," Human Organization, XI, 3 (Fall, 1952), 34-37 and my 
"Twelve Years Later: An Analys is of Field Experience," American Journal of Sociology, LXIII, 2 (Sept. 1957), 133-142.

Given these field difficulties and my preoccupation with other matters, it was not possible for me to compare systematically the statements and practices or behavior of my informants. Nevertheless, since so few data on the eta are available, the statements in and of themselves have value.

${ }^{10}$ According to my informants, the status of butcher in Japan has been so low that only eta would undertake this work.

11 Families having no son will adopt the husband of a daughter in order to continue the name. A marriage entered into under these conditions is called mukoyoshi.

12 Properly speaking, Mr. D. and Mr. H. (case 9) would be called Kibei, a term given to those Nisei who have had considerable education in Japan.
${ }^{13}$ See reference note 11.

${ }^{14}$ While the eta have long been the obvious scapegoats of the social system of Japan, hatred of inu or stoolpigeons also has some historical precedent. In Japan, the police informer was greatly feared, and in the U. S. likewise, as many of the Japanese had entered the country illegally and feared the immigration authorities and attributed their apprehension to the activities of inu. See Thomas and Nishimoto, op. cit., p. 21, n. 62.

15 This observation is not original. A parallel example during World War II may be found in the attitude of the U.S. public toward German Americans as compared with Japanese Americans. Relatively little hostility was directed at the first group, even though they had served as scapegoats during World War I, while much irrational hostility was directed at the Japanese Americans. 